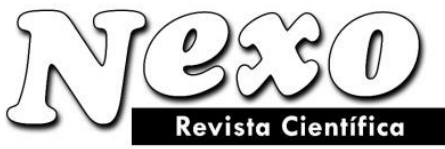

ISSN-E 1995-9516

Universidad Nacional de Ingeniería COPYRIGHT @ (UNI). TODOS LOS DERECHOS RESERVADOS http://revistas.uni.edu.ni/index.php/Nexo https://doi.org/10.5377/nexo.v34i06.13184

\title{
Reliability of construction of nuclear power facilities in the global energy market
}

\section{Fiabilidad de la construcción de instalaciones de energía nuclear en el mercado energético global}

\author{
Pyotr Grigoryevich Grabovy ${ }^{1, *}$, Sergey Aleksandrovich Baronin ${ }^{2,3}$, Vitaly Viktorovich Berezka ${ }^{1}$ \\ ${ }^{1}$ National Research Moscow State University of Civil Engineering (NIU MGSU), Moscow, Russian \\ Federation \\ ${ }^{2}$ Penza State University of Architecture and Construction, Penza, Russian Federation \\ ${ }^{3}$ International Mortgage and Real Estate Academy (MAIN), Moscow, Russian Federation \\ *email: osunkkaf@mgsu.ru
}

(recibido/received: 18-octubre-2021; aceptado/accepted: 02-diciembre-2021)

\begin{abstract}
Purpose: development of conceptual provisions, methodical approaches and practical recommendations about modeling and integrated management at a pre-investment stage of nuclear power construction facilities in the international energy construction market. Materials and methods: a set of the interrelated methodological approaches based on the theory of complex systems life cycle, methods of abstraction, comparison, analysis, synthesis, opposition, modeling, forecasting, expert assessments, risk theory and others. The research is conducted with the use of open data resources of the International Energy Agency (IEA), International Atomic Energy Agency (IAEA), World Nuclear Association (WNA), Nuclear Energy Agency under OECD and ROSATOM State Corporation open statistical data. Results: Features of the modern global world market of nuclear power construction, as well as the role and place of Russia in it, are considered. A comprehensive review of the literature on the studied problems is accomplished. A methodology for modeling the organizational and economic reliability (OER) of complex systems is suggested. Modeling of the structural components of the life cycle (hereinafter $\mathrm{LC}_{\mathrm{i}-\mathrm{j}}$ ) of an investment project for the NPP construction on the international market in the conditions of high competition is proposed.
\end{abstract}

Keywords: feasibility study, international construction; non-failure operation, NPP construction.

\section{RESUMEN}

Objeto: desarrollo de disposiciones conceptuales, enfoques metódicos y recomendaciones prácticas sobre modelización y gestión integrada en una etapa de preinversión de instalaciones de construcción de energía nuclear en el mercado internacional de construcción de energía. Materiales y métodos: conjunto de enfoques metodológicos interrelacionados basados en la teoría del ciclo de vida de sistemas complejos, métodos de abstracción, comparación, análisis, síntesis, oposición, modelización, previsión, evaluaciones de expertos, teoría de riesgos y otros. La investigación se lleva a cabo con el uso de recursos de datos abiertos de la Agencia Internacional de Energía (AIE), la Agencia Internacional de Energía Atómica (OIEA), la Asociación Nuclear Mundial (WNA), la Agencia de Energía Nuclear de la OCDE y los datos 
estadísticos abiertos de la Corporación Estatal ROSATOM. Resultados: Se consideran las características del mercado mundial moderno de la construcción de energía nuclear, así como el papel y el lugar de Rusia en él. Se realiza una revisión exhaustiva de la literatura sobre los problemas estudiados. Se sugiere una metodología para modelar la confiabilidad organizacional y económica (REA) de sistemas complejos. Se propone el modelado de los componentes estructurales del ciclo de vida (en adelante LCi-j) de un proyecto de inversión para la construcción de $\mathrm{CN}$ en el mercado internacional en condiciones de alta competencia.

Palabras claves: estudio de viabilidad, construcción internacional; operación sin fallas, construcción de centrales nucleares.

\section{INTRODUCTION}

A promising direction for the development of domestic nuclear energy companies is their participation in the international market for the construction of nuclear power plants. The peculiarities of the global nuclear construction market include the formation of an ever-growing demand for NPP power units. By the end of 2020, 442 NPP power units with a total installed capacity of $392.5 \mathrm{Kw}$ are operating in 31 countries, providing $10.4 \%$ of the world's electricity needs (IAEA data).

According to the IEA forecast, by 2040, due to the growth of the consumption market by an average of 1.6 times, it is planned to increase the share of nuclear energy in global energy production to $12 \%$, which corresponds to the volume of the input capacity of 624 GW NPP.

The analysis of the features of the global NPP construction market has shown that the main problem of its development is the uncertainty of the completion of NPP projects, that is, the volume of commissioning of new capacities, as well as the beginning of new construction (IEA forecasts). The sustainable development scenario (SDS), developed at the IEA, requires the annual commissioning of new nuclear facilities in the amount of $15 \mathrm{GW}$. It is proved that this indicator for the period from 2011 to 2020 is on average 50-60\% lower than required in accordance with the developed SDS scenario.

The interval of the unit cost of capital expenditures (overnight) in the foreign market of NPP construction is in the range of $\$ 6.500$ - $\$ 12.250$ USD per $1 \mathrm{~kW}$ of installed nuclear power, it varies by country, has a tendency to decrease, since it should be competitive with alternative energy sources.

Increasing the export potential of domestic nuclear energy investment projects is possible only by solving the problem of ensuring organizational and economic reliability (hereinafter referred to as OER) of their implementation at the pre-investment stage in terms of intensity, which includes criteria for the duration and cost of construction. OER is affected by violations of the start dates of the main phase of NPP construction, excess of the contract cost due to the presence of high investment risks not taken into account at the pre-investment phase of construction. This requires the development of a mechanism for managing the entire life cycle of construction, taking into account minimizing not so much the amount of capital costs, but reducing the cost of overall costs of the NPP life cycle, i.e. the cost of owning the NPP life cycle for end users.

Currently, the largest developer in the foreign market of nuclear power construction is the state corporation Rosatom, which implements large-scale technically complex investment mega-projects of nuclear power plants. The subjects of the analysis are a number of investment mega-projects for the construction of nuclear power plants abroad, implemented in the last decade, as well as retrospective data on the construction of nuclear power plants over the past 30 years. 
An analysis of the functioning of the global nuclear power plant market showed that as of July 01,2020 , 52 nuclear power plant reactors with a total capacity of 53,475 MW were being built in 17 countries in the world. The maximum number of power units is being built in China (15 or about 30\%), India (7 or $13.5 \%$ ), South Korea and the United Arab Emirates (4 or about 8\% each), Russia (3 or about 6\%). Two power units in each country are being built in Bangladesh, Belarus, Pakistan, Slovakia, Turkey, the United Kingdom, and the United States. One NPP power unit is under construction in each country: Argentina, Finland and France.

One of the most important trends in the development of the global nuclear power plant construction market at the moment are:

- projected growth in demand for the NPP construction according to the Sustainable Development Scenario (SDS) developed by the IEA;

- presence of key leading countries with a closed (captive) market for the NPP construction (Russia, the USA, France, Canada), which are also exporters of nuclear projects;

- emergence of the current leadership in the NPP construction in China (30\% of the market), which is focused on attracting new NPP technologies with the condition of their transfer;

- intensive growth of nuclear construction in developing countries (Africa, Asia, Latin America) and in the countries-newcomers to the nuclear energy club. Currently, the share of these countries is 10 power units under construction, or about $20 \%$ of the market. These countries mostly lack their own funds for construction. This requires the implementation of new financing schemes, starting with the introduction of modern mechanisms of public-private partnership, diversification of funding sources, attracting large investments in the nuclear energy facilities construction projects, the introduction of project management schemes for the entire life cycle of a build-own-operate NPP;

-Russia's leading role in the global nuclear power plant market, where it is represented by the engineering division of Rosatom State Corporation ( $80 \%$ of the Group's revenue consists of projects on the international nuclear construction market or $26 \%$ of the global market). Russia ranks first in the world in the NPP construction, implementing projects for the construction of power units in Europe, the Middle East, North Africa and the Asia-Pacific region (Belarus, Finland, Hungary, Turkey, Iran, China, Vietnam, India, Egypt, Bangladesh).

As of mid-2020, the capacity of the global nuclear construction market in best-case scenario is estimated by the authors at about 500 billion USD, with the total number of reactors under construction - 50. At the same time, the market share of Russian technology is currently estimated at $26 \%$ or 130 billion US dollars.

The statistics of the last 10 years illustrate a significant level of uncertainty and problems in the field of reliability of the implementation of international investment NPP projects. More than $60 \%$ of nuclear reactors in the world are built with a delay in the construction period and with an increase in project costs.

\section{MATERIALS AND METHODS}

\subsection{Literature review and problem analysis}

Currently, the domestic nuclear power industry is one of the most popular and large-scale. In the last decade, the global market for the nuclear power plants construction has shifted towards the third world countries. The Asian market shows the most significant growth (Koptelov, 2017). Developing countries, as a rule, lack their own funds for the construction of nuclear power units (Kobrin, 2005). As you know, 
investment projects of nuclear power plants are large-scale, covering hundreds of national and international organizations. The life cycle of construction and operation is about 100 years, the cost of a multi-unit nuclear power plant can reach 30 billion USD, which is a large amount if compared with the GDP of many developing countries. The most important task of Russian suppliers is to increase the reliability of contracts signed, the economic efficiency of projects implemented, as well as to ensure high transparency of transactions.

In the history of international NPP construction, it is customary to distinguish three echelons of countries that supply nuclear technologies (Koptelov, 2017). The first echelon includes the states that began the development of the peaceful nuclear industry in the 1950s and 60s. These are the USA, Great Britain, the USSR and Canada. Later, they were joined by the second echelon countries: Germany, Japan, France, Sweden, the Czech Republic, Italy. In the last fifteen years, new importers of nuclear technologies have appeared - South Korea and China (the third echelon) (The NPP Market Transmutations, 2013).

The implementation of NPP construction projects abroad by the Russian State Corporation Rosatom falls into the category of large complex investment and construction projects (in accordance with the UNIDO rules), which are characterized by (IAEA, 2015): large-scale investments (up to 30 billion USD); long term implementation (10-15 years, including design, construction and launch, as well as 60 years of operation); special attention is paid to safety issues throughout the entire life cycle.

Special attention is paid to the issues of competitiveness of nuclear construction developers (engineering companies), as well as the security system improvement issues (Leontyev, 2019). At the same time, improving the efficiency and quality of services is an important condition for promoting domestic nuclear power equipment to the world market. The main factors confirming the development of the nuclear industry are the following: an annual increase in the world's population and, as a result, an increase in the need for energy resources and an increase in electricity consumption; annual GDP growth; an increase in the volume of accumulated greenhouse gases and environmental degradation; an increase in energy prices, an increase in payments for carbon dioxide emissions; an increase in installed capacity in the nuclear industry (Rogozyansky, 2007).

Unlike in the past, when there was a narrow choice of suppliers and types of reactors, today the international nuclear construction market is becoming increasingly saturated with a variety of projects with particularly competitive requirements in terms of price factors.

For Russia, the NPP export is a promising direction of development, taking into account the global market situation, national competitiveness and the achieved positions in the market. The task of "the export potential increase" of nuclear energy is fixed in the documents of the Ministry of Economic Development (2015) and in the Energy Strategy of Russia (2009), both the current one until 2030, and in the project being developed until 2035.

A number of studies carried out by Russian scientists (Solovyova y Kharitonov y Shmakov, 2018) have revealed a number of problematic aspects of the feasibility of NPP construction projects, namely, systematic exceeding of construction deadlines, exceeding the volume of initial investments, etc.

It should be noted that according to Russian practice, the general contractor scope of responsibility for the NPP construction differs from that of the EPCM company, which is accepted in foreign practice. Russian engineering companies can conclude contracts for various project stages, volumes of services and supplies within the framework of the NPP construction project (Rosatom State Corporation, 2021) within the framework of intergovernmental agreements. 
International construction involves not only the uncertainties inherent in an international transaction, but also the entire set of risks inherent in large and complex investment and construction projects for the origin country of the participating company. In the absence of an intergovernmental agreement, international construction projects are more vulnerable to disputes arising from factors such as differences in the legal regulation of contracts, cultural characteristics, language barriers, and technical standards (Liu et al. 2017).

According to the results of disputes data studies (Liu et al. 2019), the main causes of disputes in the course of international projects were identified: "customer related" (for example, delayed contract payments, an increase in the volume and scale of the project, unrealistic expectations or requirements); "contractor related" (for example, ignorance of the geographical conditions of the project, contractor's financial problems, incomplete understanding of the relevant local laws and regulations); "contract related" (for example, different interpretations of the contract terms, unclear procedure for adjusting the preliminary amounts, unclear definition and types of defects, unjustified distribution of risks in the contract); "external" factors (for example, changes in the economic situation in the country, sanctions that lead to significant fluctuations in the exchange rate of the national currency, increasing the cost of construction or devaluing potential revenue).

An economic and mathematical model for the analytical calculation of NPP investment efficiency losses due to delays in their commissioning is given in the article (Solovyova y Kharitonov y Shmakov, 2018).

The methodology for NPP construction schedule delay risk assessment and this risk assessment in international turnkey NPP projects is presented in the study (Hossen y Kang y Kim, 2015). To conduct the questionnaire survey, the authors used the method of hierarchy analysis (AHP, analytical hierarchy process) and the relative importance index (RII, relative importance index), and the construction schedule delay risk was assessed qualitatively and quantitatively by the severity and frequency of factors contributing to the schedule delay based on the data obtained, the authors identified factors of three levels that contribute to the occurrence of delays.

The analysis of the NPP construction experience shows the presence of specific problems that occur during the implementation of complex mega-projects. The cost of a nuclear reactor represents, first of all, a significant amount of capital costs. Therefore, the construction schedule delay in the field of risks can be critical in terms of lost income and interest on capital expenditures (IAEA, 2012).

The average structure of capital expenditures by types of activities on the global NPP construction market has been established, including: design, architecture, engineering and licensing $-5 \%$; project engineering, procurement and construction management-7\%; construction and installation work-61\%; site development and general construction work-20\%; transportation-2\%; commissioning and first fuel loading-5\%. At the same time, it is proved that the NPP construction costs significantly depend on the cost of capital.

Budget overruns and delays in the schedule for new generation NPP construction projects in recent years indicate that the nuclear industry still uses unsuccessful and outdated methods of managing and controlling NPP projects (KPMG International, 2011). If the project completion dates are postponed for a year, the levelized cost of electricity increases by about 8-10\% (Harris et al. 2013).

A number of studies of the international NPP construction market confirm the importance of formalizing the processes of modeling and risk management of the pre-investment phases of the nuclear energy facilities construction (Grabovy y Berezka, 2019, 2021; Chernyakhovskaya y Berezka, 2020). A very key issue is the structuring of Russian strategies for the sale of NPP projects on the international market 
(Grabovy y Berezka, 2020), as well as the analysis of the problems of identifying the specifics of project and risks management of the general contractor (Berezka y Roehrl, 2019).

It is very important to use the assessment and management of the entire NPP construction life cycle, while taking into account both the duration and the cost of the capital construction projects life cycles from the viewpoint of estimating the ownership cost for end users (Baronin y Yankov y Bizhanov, 2014; Kulakov y Baronin, 2018). The use of this principle regarding the assessment of the ownership cost of NPP life cycles includes not only the development stage, but also the operation stage, with all specifics of nuclear construction abroad (Berezka y Roehrl, 2019). This contributes to the transition from contract development systems to models such as "contracts for the NPPs life cycle" with the set up, sale and management of the entire NPPs life cycle on the principle of "build-own-operate" and the formation of innovative Russian sales strategies for investment and construction projects for the NPP construction in international markets (Chernyakhovskaya y Berezka, 2019).

We will also mention the studies of scientists Locatelli, Lovering, Gilbert, Escobar and others on the subject, who studied the risks and trends of budget uncertainty in the planning and implementation of NPP construction projects: in works of J.R. Lovering, A. Yip, T. Nordhaus (2016) and A. Gilbert et al. (2017) considered in a global perspective; in I.M. Shafiqul and T.H. Bhuiyan (2020) - in France; in L. Escobar (2014) - in Bangladesh and in I. Ruuska et al. (2011) - in Finland.

\subsection{Methodology}

At the initial stage of methodological modeling, additional expert studies of the ranks of the main risk groups for the implementation of NPP investment projects on the international energy market were conducted. Thirty industry experts were invited to a representative sample. They selected the following priorities of the OER, arranged in descending order: reliability of assessment and compliance with the initial contract cost of construction (rank 1); reliability of assessment and compliance with the contract period of construction (rank 1); reliability of structuring and management of all stages of the NPP construction life cycle (rank 2); minimizing of the pre-contract construction period (rank 3); reliability of design solutions (rank 4); sufficiency of the managerial and production potential of construction organizations (rank 5); stability of legislation and regulatory framework (rank 6); availability of an effective project management model (rank 7); readiness of the nuclear production infrastructure of construction and its advanced nature of construction (rank 8); the readiness of the nuclear infrastructure of power transmission systems to consumers (rank 8); the effect of serialization and standardizing (rank 9).

Expert studies proved that the key criteria for managing the OER of NPP projects is the reliability of investment decisions of NPP projects to meet the deadlines and construction costs (rank 1) taken at the early pre-investment stages of the life cycle (LC). The second most significant aspect of reliability was the issue of structuring and managing all stages of the NPP construction life cycle. This predetermined the two-component structure of the developed methodology. First, these are the methodological OER modeling basis on compliance with deadlines and costs. Secondly, it is a methodological modeling of the life cycle structure of an investment project according to the essential stages of its implementation.

The methodology's first component development provides for the priority of the provision on the importance of monitoring the reliability of investment decisions according to the safety indices on the basis of compliance with both the deadlines and the cost of construction. The simultaneous consideration of these two factors of reliability is identified in the study as the construction intensity.

According to the intensity of NPP construction indicators, the OER is suggested to be considered as a multiplicative system of two-component structure, which will allow modeling, monitoring and forecasting 
of these indicators both at the early pre-investment phase and at the subsequent phases of the LC reproduction process, construction and operation.

From the standpoint of the essential understanding of the OEN as the reliability of the investment intensity for the $i-j$ stages of the LC, it should be noted as a system of mutual compliance with reliability criteria, having an initial reference point equal to one, with its subsequent "dispersion" under the influence of the organizational and economic elements of the entire system of the Investment and Construction Project (ICP) of the NPP construction.

Thus, organizational and economic reliability (OERi-j) is a step-by-step process with its subsequent probabilistic transformation due to the risk entropy - from zero approximating values (in a risk-free area the calculated reference point starts at zero $\left(\mathrm{OER}_{\mathrm{i}-\mathrm{j}}\right)$ to one from the impact of the risks of implementing the NPP construction ICP (in a critical area).

In the most general terms, this methodological approach to formalizing $O E R_{i-j}$ by stages of $L_{i-j}$ can have the following form with the target function of minimizing the deviations of $\Delta \mathrm{OER}_{\mathrm{i}-\mathrm{j}}$ to the minimum possible values:

$$
-\mathrm{OER}_{\mathrm{i}}^{0}\left[\mathrm{LC}_{\mathrm{i}}{ }^{0}\right] \rightarrow \mathrm{OER}_{\mathrm{i}+1}\left[\mathrm{LC}_{\mathrm{i}+1}\right] \rightarrow \mathrm{OER}_{\mathrm{i}+2}\left[\mathrm{LC}_{\mathrm{i}+2}\right] \rightarrow \ldots \mathrm{OER}_{\mathrm{i}-\mathrm{j}}\left[\mathrm{LC}_{\mathrm{i}-\mathrm{j}}\right] \rightarrow \Delta \mathrm{OER}_{\mathrm{i}-\mathrm{j}}(\mathrm{min})
$$

This target function of minimizing the deviations of the $\mathrm{OER}_{\mathrm{i}-\mathrm{j}}$ to the minimum possible values $\left(\triangle \mathrm{OEN} \mathrm{N}_{\mathrm{i}-}\right.$ ${ }_{j}(\min )$ ) determines the contractual priorities of the management of the OER $\mathrm{i}_{\mathrm{i}-\mathrm{j}}$ of the entire $\mathrm{LC}_{\mathrm{i}-\mathrm{j}}$ of the NPP construction.

As it is known, at the pre-investment stage, according to the UNIDO methodology, a preliminary project feasibility study (PFS) is being developed, which is subject to clarification at the stage of concluding the final contract and approving the project under the section the Construction Organization Project (COP). Taking into account these circumstances, the calculated methodological scheme of OER ${ }_{\mathrm{i}-\mathrm{j}}$ (formula 1) for the stages of $\mathrm{LC}_{\mathrm{i}-\mathrm{j}}$ can look as follows:

$$
-\mathrm{OER}_{\mathrm{PFS}}\left[\mathrm{LC}_{\mathrm{i}-\mathrm{j}}^{\mathrm{PFS}}\right] \rightarrow \mathrm{OER}_{\mathrm{i}}^{0}\left[\mathrm{LC}_{\mathrm{i}}^{0}\right] \rightarrow \mathrm{OER}_{\mathrm{i}+1}\left[\mathrm{LC}_{\mathrm{i}+1}\right] \rightarrow \ldots \mathrm{OER}_{\mathrm{i}-\mathrm{j}}\left[\mathrm{LC}_{\mathrm{i}-\mathrm{j}}\right] \rightarrow \Delta \mathrm{OER}_{\mathrm{i}-\mathrm{j}}(\mathrm{min})
$$

The developed method assumes modeling the $\mathrm{OER}_{\mathrm{i}-\mathrm{j}}$ indicator according to the intensity criterion through two main components:

- first, it is the organizational reliability $\left(\mathrm{OR}_{\mathrm{i}-\mathrm{j}}\right)$ for compliance with the accepted deadlines of the activitybased network of construction $\left(\mathrm{T}_{\mathrm{oi}}\right)$ in the NPP construction life cycle as a system of mutual compliance of the decisions made on the $\mathrm{T}_{\mathrm{oi}}$ at the later stages of the $\mathrm{LC}_{\mathrm{j}}$ relative to the earlier $\mathrm{LC}_{\mathrm{i}}$. Any positive or negative deviation in the construction period leads to a decrease in $\mathrm{ORi}-\mathrm{j}$, i.e., it is proposed to use the data of the ratios of the constructed in time NPP power units $\left(\mathrm{N}^{+}\right)$to their total number $\left(\mathrm{N}_{0}\right)$ for a certain calculation period. In this case $\mathrm{OR}_{\mathrm{n}}$, it is defined as follows:

$$
\mathrm{OR}_{\mathrm{i}-\mathrm{j}}=\mathrm{N}^{+} / \mathrm{N}_{0}
$$

This indicator $\mathrm{OR}_{\mathrm{i}-\mathrm{j}}$ characterizes the probability of failure-free construction of NPP power units and it can be used if there are statistical data available;

- secondly, it is the economic reliability $\left(\mathrm{ER}_{\mathrm{i}-\mathrm{j}}\right)$ of compliance with the construction cost indicators $\left(\mathrm{S}_{\mathrm{i}}{ }_{\mathrm{i}}\right)$ in the life cycles of the NPP construction as a system of mutual compliance of the decisions made on $\left(\mathrm{S}_{\mathrm{i}}{ }^{0}\right)$ at the later stages of the $\mathrm{LC}_{\mathrm{j}}$ relative to earlier $\mathrm{LC}_{\mathrm{i}}$. 
The two-component localization of the constituents of the $\mathrm{OER}_{\mathrm{i}-\mathrm{j}}$ makes it possible to carry out an integral assessment of the $\mathrm{OER}_{\mathrm{i}-\mathrm{x}}$ as a process of synthesis of the investment's intensity (capital investments) through organizational $\left(\mathrm{OR}_{\mathrm{i}-\mathrm{j}}\right)$ and economic $\left(\mathrm{ER}_{\mathrm{i}-\mathrm{j}}\right)$ reliability at the $\mathrm{i}-\mathrm{j}$ stages of the life cycle (formula 4):

$$
-\mathrm{OER}_{\mathrm{i}-\mathrm{j}}=\mathrm{OR}_{\mathrm{i}-\mathrm{j}} \mathrm{x} \mathrm{ER}_{\mathrm{i}-\mathrm{j}}
$$

Where $\mathrm{OR}_{\mathrm{i}-\mathrm{j}}$ - the organizational reliability of the solution for the construction period, determined according to the calculation scheme shown in Figure 1.

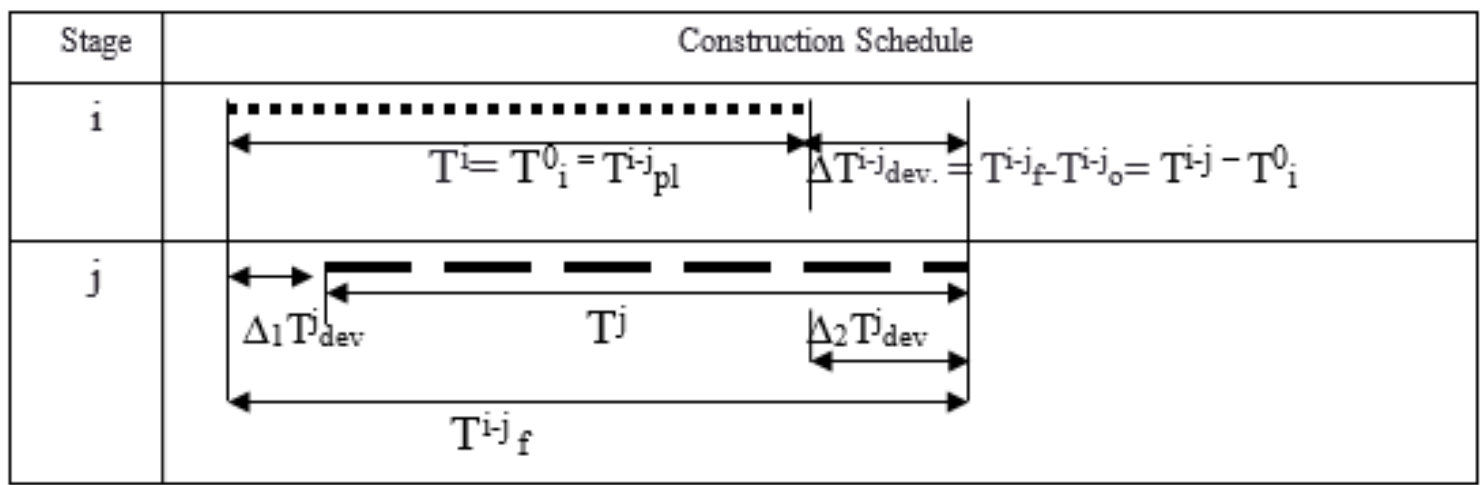

Figure 1. Calculation scheme for determining the parameters of organizational reliability $\mathrm{OR}_{\mathrm{i}-\mathrm{j}}$ by stages $\mathrm{LC}_{\mathrm{i}-\mathrm{j}}$

The calculation scheme for identifying construction period failures provides for the allocation of two types of deviations of the actual terms:

1. Failures relative to the start point of the calendar schedule $-\Delta 1 \mathrm{~T}_{\mathrm{dev}}^{\mathrm{j}}$;

2. Refusals relative to the end point of the calendar schedule $-\Delta 1 \mathrm{~T}_{\mathrm{jev}}^{\mathrm{j}}$.

These types of failures, if any, must be summed up and taken into account in the denominator of the formula (5). The numerator always contains the planned indicators of the basic $\left(\mathrm{T}^{\mathrm{i}}\right)$ or zero $\mathrm{i}$-stage $\left(\mathrm{T}^{0}{ }_{\mathrm{i}}\right)$, the value of which, in case of failure-free execution, should be the same in duration at the $j$-stage of the $\mathrm{LC}_{\mathrm{i}-\mathrm{j}}$. If there are deviation failures, the duration of $\mathrm{T}^{\mathrm{j}}$ increases, which leads to the manifestation of $\mathrm{OR}_{\mathrm{i}-\mathrm{j}}$ dispersal processes in a sequential chain of stages of the life cycle of NPP construction.

$$
-\mathrm{OR}_{\mathrm{i}-\mathrm{j}}=\mathrm{T}^{\mathrm{i}-\mathrm{j}}{ }_{\mathrm{pl}} \mathrm{x}\left[1 / \mathrm{T}^{\mathrm{i}-\mathrm{j}} \mathrm{pl}+\Delta \mathrm{T}^{\mathrm{i}-\mathrm{j}} \mathrm{dev}\right]=\mathrm{T}^{\mathrm{i}} \mathrm{x}\left[1 / \mathrm{T}^{\mathrm{j}}+\sum \Delta_{1.2} \mathrm{~T}_{\mathrm{dev}}^{\mathrm{j}}\right]
$$

The second component of OERi-j according to ERi-j is determined in the same way on the basis of failure control by the value of cost deviations $(\mathrm{Si})$.

$$
\left.-\mathrm{Er}_{\mathrm{i}-\mathrm{j}}=\mathrm{S}_{\mathrm{o}}^{\mathrm{i}} \mathrm{x}\left[1 / \mathrm{S}_{\mathrm{pl}}^{\mathrm{j}}+\Delta \mathrm{S}_{\mathrm{dev}}^{\mathrm{j}}\right]=\mathrm{S}^{\mathrm{i}} / \mathrm{S}^{\mathrm{J}}=\mathrm{S}_{\mathrm{pl}}^{\mathrm{i}} \times{ }^{[} 1^{/} \mathrm{S}_{\mathrm{pl}}^{\mathrm{i}}{ }^{+}\left(\mathrm{S}^{\mathrm{j}}-\mathrm{S}^{\mathrm{i}}\right)_{\mathrm{pl}}\right]
$$

At the same time, the cost $\left(\mathrm{S}_{\mathrm{i}}\right)$ at the i-stage is both basic, zero $\left(\mathrm{S}_{\mathrm{i}}{ }_{\mathrm{i}}\right)$ and planned $\left(\mathrm{S}_{\mathrm{pl}}^{\mathrm{i}}\right)$ at the same time.

$$
\text { - } \mathrm{S}_{\mathrm{i}}=\mathrm{S}_{\mathrm{i}}^{0}=\mathrm{S}_{\mathrm{pl}}^{\mathrm{i}}
$$

The $\mathrm{ER}_{\mathrm{i}-\mathrm{j}}$ formula is applicable under the condition that $\mathrm{S}_{\mathrm{j}}$ is bigger than or equal to $\mathrm{S}_{\mathrm{i}}$. 
The proposed methodological approach to determining the OERi-j reflects the author's position on the studied problem of modeling multi-stage processes of the life cycle of NPP development in terms of the investment intensity of nuclear power construction. It develops and complements existing research in the field of the theory of organizational and economic reliability of the implementation of large complex investment projects.

The second final part of the methodology is the modeling of the structure of the life cycle of NPP construction (Figure 2).

The completed structuring provides for the allocation of the following main stages of the NPP life cycle:

Firstly, $\mathrm{LC}_{1}$ is the first pre-investment stage of the conceptual type with a preliminary feasibility study and a final feasibility study for NPP - $\mathrm{LC}_{1}$. Its structure conforms to the classical requirements of the UNIDO methodology and takes into account the specifics of international standards for the NPP construction, as well as country-specific legislative features and safety regulations. The presence of intergovernmental agreements, the choice of a site and the investor's approval of PFS gives the basis for concluding a contract, where the Russian engineering division signs it in the form of EPCM contracts. It is proposed to develop the "single window" principle and manage the entire life cycle, up to contracts for the construction and operation life cycles. This approach allows the Russian supplier to (1) ensure the construction of a turnkey nuclear power plant on the terms of an EPCM contract; (2) model the contract indicators of international nuclear projects according to the criterion of minimizing the cost of owning a nuclear power plant for end users, and not only the specific cost of construction given for $1 \mathrm{MW}$ of commissioned capacity.

According to foreign practice, the engineering company (EPCM) is responsible for the integration of the entire project, its final cost (including design operational indicators) and the terms of the turnkey contract implementation to the customer, including fully planning, constructing and commissioning the NPP power unit in accordance with the specifications and requirements of the customer.

Secondly, this is the design stage- $\mathrm{LC}_{2}$, where all previously made decisions in the PFS are specified in the COP section.

Thirdly, this is the construction stage- $\mathrm{LC}_{3}$, which consists of the preparatory period, the stage of creating the production base and infrastructure, as well as the main period (counted from the concreting of the first layer at the reactor compartment). This stage is divided into start-up complexes, construction stages associated with the commissioning of power units.

Fourth, the operation stage $\left(\mathrm{LC}_{4}\right)$ and the final period $-\mathrm{LC}_{5}$ - the decommissioning of power facilities.

The model of the $\mathrm{LC}_{\mathrm{i}-\mathrm{j}}$ structure proposed in Fig.2 in relation to the OER $\mathrm{i}_{\mathrm{i}-\mathrm{j}}$ methodology allows us to formalize the system of evaluated criteria with the allocation of reference points for decisions made by the intensity indicator. Such zero moments can be both decisions of the stage of the approved PFS $\left(\mathrm{LC}_{1}\right)$, the contract, as well as data from the COP as part of the project. 


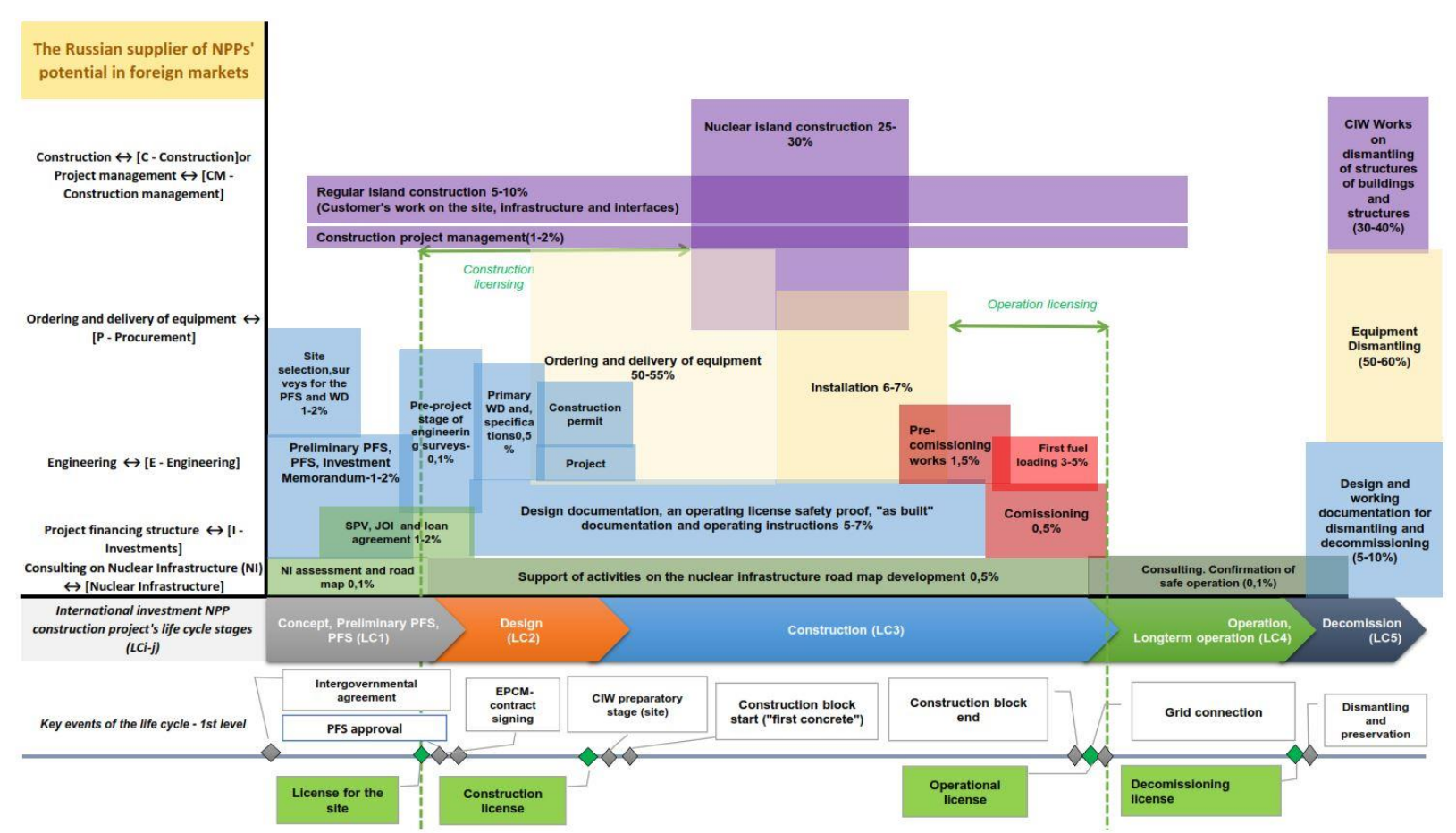

Figure 2. Modeling of the $\mathrm{LC}_{\mathrm{i}-\mathrm{j}}$ main structural components of the NPP construction investment project in the international nuclear energy market against the background of priority of engineering companies, EPCM contracts and a "build-own-operate" management strategy

\section{RESULTS}

3.1. Analysis of the international NPP construction market according to the developed integral indicator

The analysis of the problems of organizational reliability (hereinafter referred to as $\mathrm{OR}_{\mathrm{n}}$ ) of the implementation of NPP investment projects in the international NPP construction market according to the criterion of construction schedule delay showed that out of 52 NPP units under construction on 01.07.2020, 33 units or $63.5 \%$ were built with a delay of the previously accepted deadlines (Figure 3 ).

The performed study of the $\mathrm{OR}_{\mathrm{n}}$ by the criterion of whether there is a delay of the planned NPP power units commissioning dates on the basis of open data from the IEA, the IAEA, the WNA, the OECD, showed that the divisions of the Rosatom Group are characterized by relatively high reliability of the previously planned construction schedules. So, according to the indicator, the $\mathrm{OR}_{\mathrm{n}}$ for Russian power units is 0.67. Only the United Kingdom and Bangladesh have a $\mathrm{OR}_{\mathrm{n}}=1$, the $\mathrm{OR}_{\mathrm{n}}$ for China equals to-0.6, Turkey and Pakistan-0.5, India-0.29. In countries such as South Korea, the United Arab Emirates, Belarus, Slovakia, the United States, Argentina, Iran and Japan, $\mathrm{OR}_{\mathrm{n}}$ is very low, since all power units are being built with a delay.

This indicator, $\mathrm{OR}_{\mathrm{n}}$, gives a certain local picture of the organizational and managerial factor of NPP construction, but it does not claim to be exceptional and requires additional parameters for a more comprehensive analysis. 


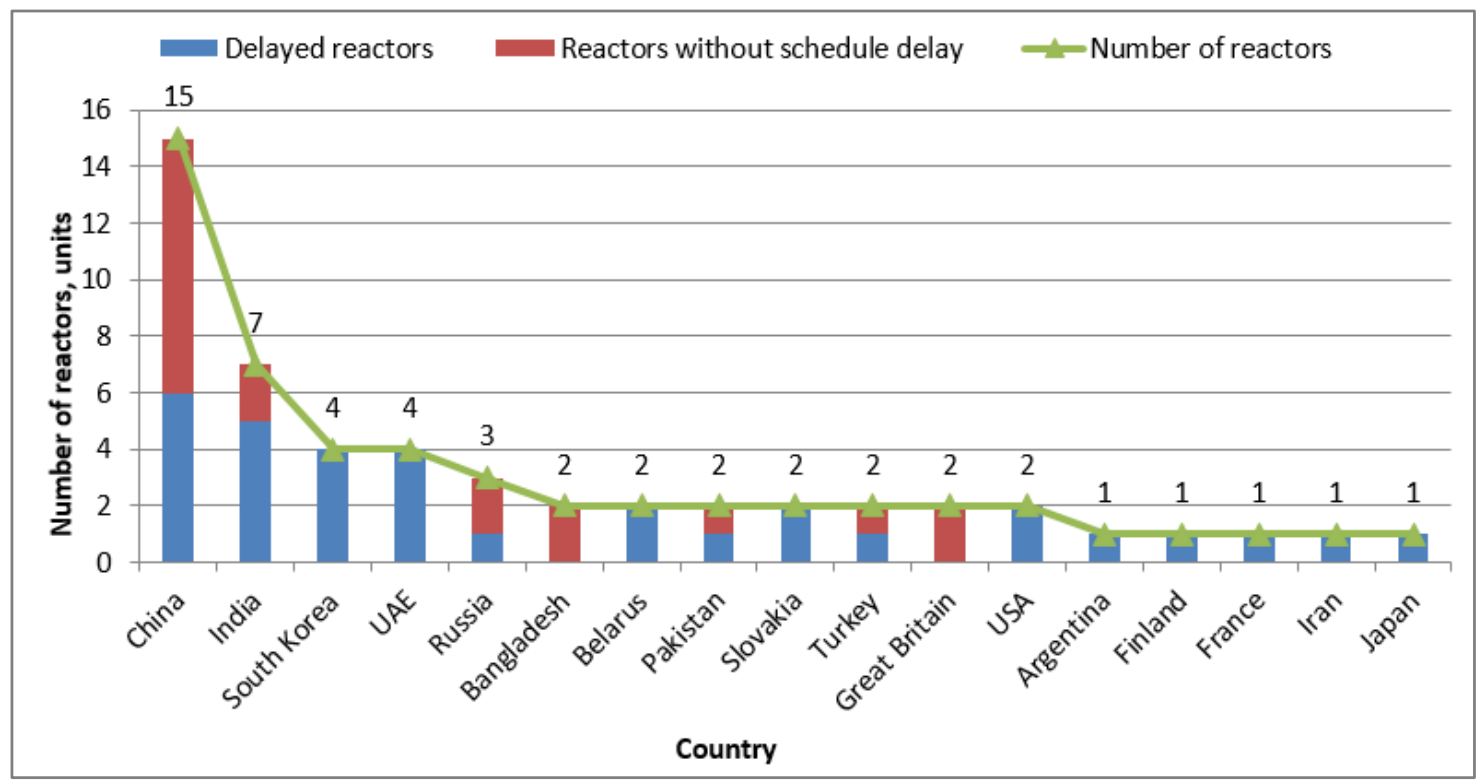

Figure 3. Analysis of the international NPP construction market by the organizational reliability of the commissioning dates of power units

An analysis of the IAEA open data (IAEA, 2021) for the period 2009-2019, illustrated by the sample of 63 NPP power units under construction, showed that the average period of the NPP power units' construction was ten years. The minimum terms in South Korea and China are 4.1 years, and in Pakistan - 5.2 years. For Russia, these indicators are 20.3 years - on average, at least 8.1 years, a maximum of 35.1 years. Significant construction period is in the USA (43.5 years).

There is a clear global trend towards an increase in the NPP construction period, associated with the tightening of their safety rules. So, for 1980-1990, the average period was about 8 years. The results obtained in recent years have an average of 10 years and are very variable.

Nine power units completed in 2018-2019 by the Chinese nuclear industry took an average of 7.6 years to build, while five Russian projects took an average of 16 years from the construction start to the grid connection, and the construction of 4 Rostov NPP power units took almost 37 years from the start of construction to the final generation of electricity. The analysis of compliance with the construction deadlines showed that, on average, the amount of schedule delays is at least $50 \%$ of the previously planned ones. The long-term perspective confirms that short construction periods remain exceptions.

3.2. Trends in the dispersion of organizational and economic reliability of the implementation of NPP investment projects by life cycle stages

The restricted and closed nature of the information regarding the planned and actual cost values and NPP construction periods in different countries creates difficulties in testing the previously proposed methodology for determining the integral indicator of the $\mathrm{OER}_{\mathrm{i}-\mathrm{j} .}$. In this regard, the author has developed an expert analytical fan model of the OER $_{\mathrm{i}-\mathrm{j}}$, (Figure 4). 


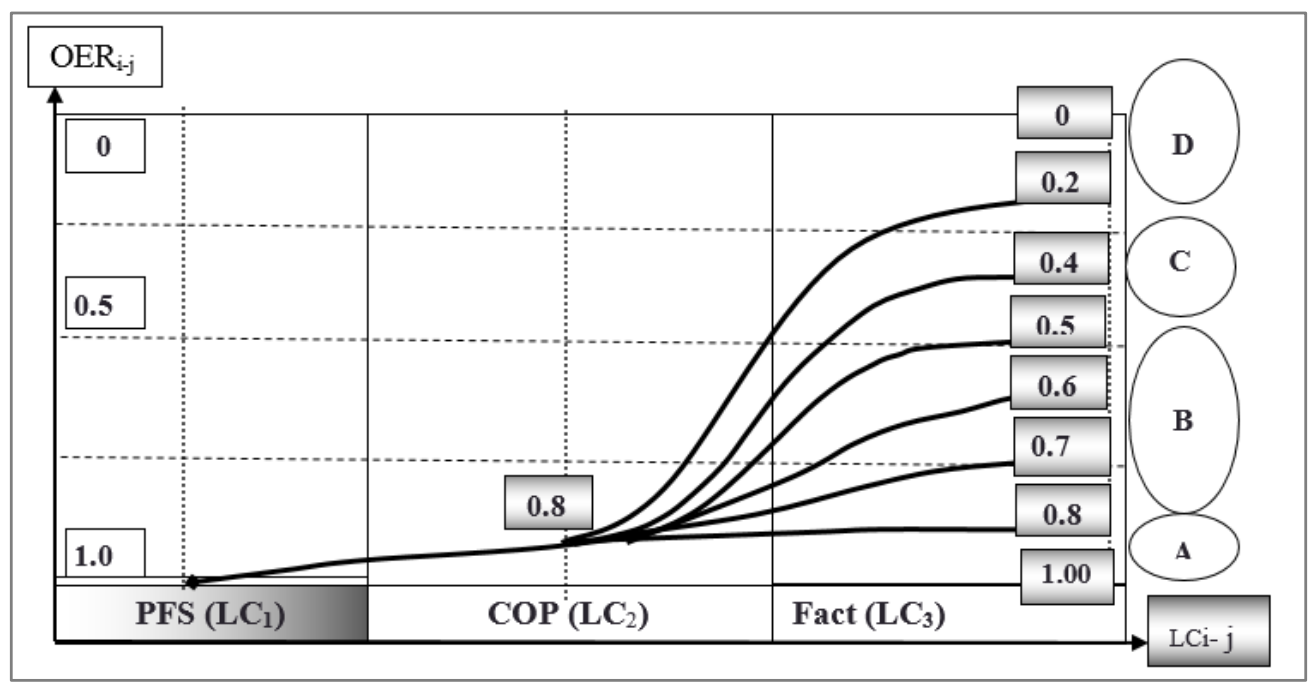

Figure 4. A fan-shaped expert-analytical model of trends in the dispersion of the basic $\mathrm{OER}_{0}$ of NPP construction by stages of the life cycle (from PFS single values to the COP and the commissioning with risk zoning of type A-E)

It is established that all market segments can be divided into 4 groups:

A. highly reliable construction projects with $\mathrm{OER}_{1-3}$ indicators from 1.0 to 0.9 . As a rule, for such projects, the organizational reliability of $\mathrm{OR}_{1-3}$ in terms of schedule can be observed with a single indicator, and $\mathrm{ER}_{1-3}$ is the value of cost failures in the range of $20 \%$. This determines the average value of $\mathrm{OER}_{1-3}$ in the range of $80 \%$ or 0.8 ;

B. reliable projects with $\mathrm{OER}_{1-3}$ from 0.79 to 0.50 ;

C. low reliability projects with $\mathrm{OER}_{1-3}$ from 0.49 to 0.20 ;

D. critical reliability projects - $\mathrm{OER}_{1-3}$ less than 0.20 .

The analysis of the ERi-j indicators showed that their average values always change even with high indices of organizational reliability. So, for projects in a high organizational reliability zone A, when $\mathrm{OR}_{1-}$ ${ }_{2}=1.0$, there is a change in the project cost associated, at least, with the processes of inflation and unaccounted for cost factors.

Calculations of the OERi-j in relation to a number of nuclear power plants of the Soviet period showed that the Zaporozhye and Balakovo NPPs were included in group A with the best construction indicators. Their final indicators of OER1-3 equal to 0.60, while for the second NPP group (Kalinin, Khmelnitsky, Rostov and South Ukrainian), this indicator was 0.34 The obtained graphs of changes in these indicators demonstrate a significant dispersion of individual basic indicators to areas of critical reliability (a highrisk area).

With regard to the current period of the global NPP construction market functioning, it is possible to estimate the $\mathrm{OER}_{\mathrm{i}-\mathrm{j}}$ only by local indicators of $\mathrm{OR}_{\mathrm{n}}$ organizational reliability type, calculated earlier, and by the average ER1-3 index of 0.8. As of 01.07.2020, this allowed us to obtain the following groups of organizational and economic reliability of the global market countries in descending order: Great Britain and Bangladesh-0.8 (type A - highly reliable); Russia, China - 0.5 (type B - reliable projects); Turkey, Pakistan - 0.4 (type $\mathrm{C}$ - low reliability projects). 
The approbation of this technique due to the difficulty of collecting a sequence of factual data is experimental by nature. The interpretation of the results obtained, as well as the content of the methodology itself, requires its own creative development.

3.3. Recommendations for modeling the integrated management system of the pre-investment OER phase, based on the multi-criteria optimization of project schedules

The key issue of modeling organizational and economic reliability is the ability to ensure the management of $\mathrm{OER}_{\mathrm{i}-\mathrm{j}}$ indicators in the early pre-investment phases. In this regard, we propose a set of decisions on multi-criteria optimization of calendar and network schedules based on the identified factor space for managing regulated risks for the Russian EPCM company operation conditions.

It is suggested to use a multi-criteria model of the decision-making task in the following form:

$$
\text { - } \mathrm{G}\left(\mathrm{W}, \mathrm{K}, \mathrm{Sc}, \mathrm{Z}, \mathrm{Q}, \mathrm{U}, \mathrm{R}, \mathrm{A}, \mathrm{OER}_{\mathrm{i}-\mathrm{j}}\right) \rightarrow \operatorname{opt}\left(\mathrm{LC}_{\mathrm{i}-\mathrm{j}} ; \mathrm{F}(\mathrm{O} ; \mathrm{E} ; \mathrm{C} ; \mathrm{X})\right)
$$

where $\mathrm{W}$ setting up the problem of the OERi-j integrated control system; $\mathrm{K}$ - the criteria field of optimization (NPV, PI, IRR, P, OER); Sc - a multi-vector field of criteria scales for assessing aggregate risks; $\mathrm{Z}$ - identification of alternative risk management strategy; $\mathrm{Q}$ - alternative ranges for a system of estimates and integral results of actions; $\mathrm{U}-\mathrm{a}$ local subsystem of subject preferences in relation to the subject of regulation; R - key (critical) rule; A - contour and algorithm optimization field; OER $\mathrm{i}_{\mathrm{i}-\mathrm{j}}-$ modeling of optimization indicators of the integrated risk management system at the pre-investment phase of NPP construction according to the construction intensity criterion; $\mathrm{LC}_{-\mathrm{i}-\mathrm{j}}$ stage modeling of optimization indicators in the engineering divisions of Rosatom State Corporation; F- adjustable factor risk space by subsystems: Project Customer (O), EPCM contractor (E), Contract risks (C), External Factors (X).

The above principles and functioning models are the basis of the developed formal heuristic algorithms for finding the optimal forecast schedule-charts for the implementation of the NPP construction project at the pre-investment phase within the framework of the integrated OER management system.

\section{DISCUSSIONS}

Undoubtedly, the attempt to synthesize the indicator of organizational and economic reliability in terms of investment intensity and duration as a system of compliance of decisions made in the life cycle of NPP construction according to local criteria of reliability of the planned deadlines and cost is of scientific and practical interest. But at the same time, solving this task one should note a number of debatable issues.

First, if the integration of the $\mathrm{OER}_{\mathrm{i}-\mathrm{j}}$ on compliance with deadlines and cost is carried out, it would be necessary to additionally perform an analysis of the correlation relationships of the indices of compliance with the cost and deadlines. It is quite possible that they require the introduction of disequilibrium adjusting indicators in the final $\mathrm{OER}_{\mathrm{i}-\mathrm{j}}$ indicator, or the use of another type of economic and mathematical interrelations of particular reliability indicators;

Secondly, the $\mathrm{OER}_{\mathrm{i}-\mathrm{j}}$ methodology as presented is of general nature and requires its own adjustments in relation to the corporate standards of a particular user. To find the integral OER $\mathrm{i}_{\mathrm{i}-\mathrm{j}}$ value, we should apply the problem of functional and statistical modeling using the bifurcation theory and the selection of indicators comparable simultaneously for two criteria: organizational reliability and economic reliability and identification of the general integral indicator $\mathrm{OER}_{\mathrm{i}-\mathrm{j}}$; 
Third, it is quite obvious that there is a need for further development of the methodology in relation to specific market segments of developing countries (Africa, Asia, Latin America) against the background of intergovernmental agreements;

Fourth, it is important to supply the methodological calculation apparatus with its orientation for digital information systems and BIM technologies, such as MULTI-D and TCM NC technologies used by the engineering divisions of the Rosatom State Corporation (OCKS of Rosatom, 2017);

Fifth, the methodology for assessing and managing the OER $_{\mathrm{i}-\mathrm{j}}$ should have a mandatory element of defining the efficiency and monitoring (managing risk areas) at the final calculation stage.

The above-mentioned range of debatable methodology issues should be attributed not so much to the shortcomings, but mainly to the prospects for its development.

\section{CONCLUSIONS}

The research carried out based on the results of the literature review, the methodology and its approbation in the context of the global NPP construction market confirmed the importance of the author's vector of scientific and practical work in the field of developing conceptual provisions, methodological approaches and practical recommendations for modeling and integrated management at the pre-investment stages of NPP construction integrated indicators of organizational and economic reliability.

A challenging research field appears due to the importance of developing fundamental and exploratory scientific research on the problem of improving the efficiency of the global nuclear construction market, which project portfolio, according to the author's optimistic estimations, as of July 01, 2020, is about 500 billion USD, with the total number of reactors under construction being 50 .

The development strategy of the State Corporation Rosatom provides for an increase in its current global market share of engineering services for the NPP construction from the current 26\% (USD 130 billion) to $40-50 \%$ (about USD 350 billion) in the perspective up to 2035. In this regard, the concept and methodology for ensuring the reliability increase in the implementation of NPP investment projects according to their terms and cost are the most important aspects to achieve competitive advantages at the early pre-investment stages.

It is established that the key criteria for managing the reliability of NPP projects are the infallibility of investment decisions of NPP projects in terms of the deadlines and construction costs adopted at the early pre-investment stages of the life cycle. This approach was proved by the calculation methodology and its approbation on the basis of the life cycle stages of NPP reproduction structuring. The main established groups of global market countries by organizational and economic reliability are shown in descending order: type A - highly reliable (Great Britain and Bangladesh); type B - reliable projects (Russia, China); type $\mathrm{C}$-projects with low reliability (Turkey, Pakistan).

As the main results of the study, the following data were obtained: current features of the global world market of nuclear construction development were defined, its capacity and share of Russia were modeled; a model was developed and analyzed according to the indicators of organizational and economic reliability; the trends of dispersion according to the fan model by the stages of the life cycle were identified; recommendations were given on the formalization of the integrated management system in the pre-investment phase based on multi-criteria optimization of calendar schedules.

The studied conceptual approach in the field of modeling and management of organizational and economic reliability of the life cycles of NPP construction and operation in global markets is supposed to 
be defined as a promising institutional tool for regulating the competitiveness growth of the engineering division of Rosatom State Corporation in order to increase the share of international nuclear power construction projects.

\section{REFERENCES}

Baronin, S.A., Yankov, A.G., Bizhanov, S.A. (2014). Assessing the cost of Real estate lifecycle contracts in Russia's present-day economy and the characteristics of the European experience. Life Science Journal, 11(8S), 249-253.

Berezka, V.V., Roehrl, A. (2019). Features of project and risks management by the contractor during construction in foreign countries. Real estate: economics, management, 1, 13-18.

Chernyakhovskaya, Yu.V., Berezka, V.V. (2019). Russian sales strategy for NPP investment and construction projects (Economic Systems) in the international market. Real estate: economics, management, 2, 53-60.

Chernyakhovskaya, Yu.V., Berezka, V.V. (2020). Russian business strategy and tactics on the world market of NPP construction (As Economic systems). In: Advances in Economics, Business and Management Research. Vol. 128. Proceedings of the International Scientific Conference "Far East Con". Atlantis Press, pp. 2203-2213.

Energy Strategy of Russia for the period up to 2030, approved by Decree of the Government of the Russian Federation No. 1715-r dated November 13, 2009. Available at: http://government.ru/docs/all/70320/

Escobar, L. (2014). Economics of nuclear power: construction costs and safety regulation. PhD thesis Ecole Nationale Supérieure des Mines de Paris, Paris.

Gilbert, A., Sovacool, B; Johnstone, P., Stirling, A. (2017). Cost overruns and financial risk in the construction of nuclear power reactors: a critical appraisal. Energy Policy, 102, 644-649. Available at: http://dx.doi.org/10.1016/j.enpol.2016.04.001

Grabovy, P., Berezka, V. (2020). Determining the reasonable degree of specialization of Russian companies participating in NPP construction abroad. IOP Conference Series: Materials Science and Engineering, 869, 062038. DOI: 10.1088/1757-899X/869/6/062038

Grabovy, P.G., Berezka, V.V. (2019). Management of organizational and technological (operational) risks of Russian contractors during the construction of nuclear power plants abroad. Real estate: economics, management, 3, 6-16.

Grabovy, P.G., Berezka, V.V. (2021). Risk modeling at the pre-investment phase of nuclear powerplant construction on the international market. Real estate: economics, management, 1, 59-69.

Harris, G., Heptonstall, P., Gross, R., Handley, D. (2013). Cost estimates for nuclear power in the UK. Energy Policy, 62, 431-442.

Hossen, M.M., Kang, S., Kim, Ch. (2015). Construction schedule delay risk assessment by using combined AHP-RII methodology for an international NPP projects. Nuclear Engineering and Technology, 47, 362-379. DOI: 10.1016/j.net.2014.12.019

IAEA. (2012). IAEA Nuclear Energy Series No. NP-T-2.7. Project management in NPP construction: 
guidelines and experience. Vienna.

IAEA. (2015). IAEA Nuclear Energy Series No. NG-G-3.1 (Rev. 1). Milestones in the development of a national infrastructure for nuclear power. Vienna.

IAEA. (2021). Power Reactor Information System. Available at: https://prisweb.iaea.org/Home/Pris.asp

Kobrin, S.J. (2005). The determinants of liberalization of FDI policy in developing countries: a crosssectional analysis. Transnational corporations, 14(1), 67-98.

Koptelov, M.V. (2017). Improving methods of cost efficiency determination and risk assessment in investment projects of foreign nuclear energy facilities construction. Ph.D. thesis in Economicd. National Nuclear Research University, Moscow.

KPMG International. (2011). Construction risk in new nuclear power projects - eyes wide open. Available at: https://docplayer.net/8661705-Construction-risk-in-new-nuclear-power-projects-eyes-wide-open.html

Kulakov, K.Y., Baronin, S.A. (2018). Modeling total cost of ownership residential Real estate in the life cycles of buildings. International Journal of Civil Engineering and Technology, 9(10), 1140-1148.

Leontyev, N.Y. (2019). A methodology for the competitiveness improvement for the nuclear sector engineering companies. Ph.D. thesis in Economics. Nizhny Novgorod State Technical University of R.E. Alekseev, Nizhny Novgorod.

Liu, J., Jin, F., Xie, Q., Skitmore, M. (2017). Improving risk assessment in financial feasibility of international engineering projects: a risk driver perspective. International Journal of Project Management, $35(2), 204-211$.

Liu, J., Li, H., Skitmore, M., Zhang, Y. (2019). Experience mining based on case-based reasoning for dispute settlement of international construction projects. Automation in Construction, 97, 181-191.

Lovering, J.R., Yip, A., Nordhaus, T. (2016). Historical construction costs of global nuclear power reactors. Energy Policy, 91, 371-382. DOI: 10.1016/j.enpol.2016.01.011

Ministry of Economic Development of the Russian Federation. (2015). The main directions of export development up to 2030 (project). Available at: http://economy.gov.ru/minec/about/structure/depSvod/2015020513. Accessed on: Jul. 1, 2021.

OCKS of Rosatom. (2017). The analytical magazine "Construction in Nuclear Industry", 3(October), 8-18 Available at: https://www.ocks-rosatoma.ru/upload/iblock/eab/OCKS 3 2017.pdf

Rogozyansky, D.O. (2007). Organizational and economic mechanism for improving the efficiency of promoting power equipment on the world market. Ph.D. thesis in Economics. Plekhanov Russian Academy of Economics, Moscow.

Rosatom State Corporation. (2021). Official website. Available at: https://rosatom.ru/production/design/stroyashchiesya-aes/. Accessed on: Jul. 1, 2021.

Ruuska, I., Ahola, T., Artto, K., Locatelli, G., Mancini, M. (2011). A new governance approach for multifirm projects: lessons from Olkiluot o 3 and Flamanville 3 nuclear power plant projects. International Journal of Project Management, 29(6), 647-660. 
Shafiqul, I.M., Bhuiyan, T.H. (2020). Assessment of costs of nuclear power in Bangladesh. Nuclear Energy and Technology, 6(3), 181-194.

Solovyova, A.P., Kharitonov, V.V., Shmakov, O.G. (2018). Effect of delays in NPP construction on investment efficiency. Higher education institutions newsletter. Nuclear power engineering, 3, 52-62.

The NPP Market Transmutations. (2013). Nuclear expert, 8(17), 10-17. 